Article

\title{
Tourist-to-Tourist Interaction at Festivals: A Grounded Theory Approach
}

\author{
Huan Sun ${ }^{1}$, Shaofeng $\mathrm{Wu}^{2}$, Yanning $\mathrm{Li}^{3}{ }^{3}$ and Guangquan Dai ${ }^{1, *(\mathbb{D})}$ \\ 1 School of Economics and Commerce, South China University of Technology, Guangzhou 510006, China \\ 2 School of Tourism, Hunan Normal University, Changsha 410006, China \\ 3 School of Hospitality and Tourism Management, University of Surrey, GU2 7XH Guildford, UK \\ * Correspondence: gqdai@scut.edu.cn; Tel.: +86-138-2619-4271
}

Received: 1 July 2019; Accepted: 23 July 2019; Published: 25 July 2019

\begin{abstract}
Although neglected in previous studies, tourist-to-tourist interaction (TTI) is a core part of festival experience. It is widely acknowledged that interactions between tourists significantly influence behavioral reactions such as desire to stay, satisfaction, and loyalty, which are important for tourism destination marketing. This study used grounded theory to obtain insights into onsite interactions between tourists and to propose a conceptual model of TTI on the Midi Music Festival in China. The model constitutes the types, drivers, and influence of TTI. Compared with mutual assistance and conflict, entertainment interaction plays an essential role in the overall evaluation of the festival experience. Individual characteristics are the internal drivers of interactions between tourists. Environmental elements including the festivalscape and social festivalscape are influential exogenous factors. Additionally, spatial locations of tourists at the venue play mediating roles between the driving elements and TTI. Since entertainment incidents construct the essential part of onsite interactions at festivals, managers can shape the atmosphere to encourage tourists to engage in interactive entertainment with others tourists. This should improve participants' overall evaluations of the festival experience as well as the sustainable development of destinations where festivals are held.
\end{abstract}

Keywords: festival tourism; interactions between tourists; tourism marketing

\section{Introduction}

Festivals have gradually become highly developed segments of the continuously expanding tourism industry, because of the closer connection between festivals and tourism [1]. Festivals can be used to shape destination image and to promote economic development of the territory where festivals are held [2]. Meanwhile, the cyclical features of festivals and the development from hallmark events to hallmark destination are very important for the sustainable development of tourist destinations. Due to the rapid growth of festival tourism industry, fiercely competitive and homogeneous festival products have become the prominent problems perplexing festival operators. Hence, they are increasingly aware of the importance of sustainable management of festivals to strengthen market position and competitive advantage [3,4].

Management of customer relationships is emphasized in service relationship marketing [5]. However, tourist-to-tourist interaction (TTI) has been overlooked in both research and practice, due to its uncontrollable nature for site or festival managers [6-8]. However, it is generally agreed that meeting people and forging new relationships are core parts of the experience, resulting from tourists' interactions with various physical and social elements $[9,10]$. As such, shared time and space make TTI critical for the overall tourist experience, which has been acknowledged in traditional service marketing and management frameworks $[7,11,12]$. TTI is the theoretical application of customer-to-customer 
interaction (CCI), which draws on the earlier servuction system model and has provided a wide range of insights [13]. After nearly two decades of development, the components and characteristics as well as influential factors of TTI have drawn academic attention [14]. Correspondingly, integral aspects of this topic have comparatively not been as fully studied as other service industries such as retailing, education, and passenger transportation [5].

Festivals are inherently social events and provide a means for people to interact and share experiences with significant others [15]. For many festival tourists, the most meaningful experiences derive from social interactions with peers rather than from specific activities [16]. Hence, TTI are essential to the festival experience and influence behavioral reactions, such as desire to stay, satisfaction, and loyalty, which are important for the sustainable development of festival destinations $[17,18]$. The existing literature considers TTI mainly in three types of activities: group tours, backpacking, and cruises; obviously, festival tourism has been neglected [19].

Considering the high dependence of interactive behaviors on the situation, existing frameworks for TTI in general tourism settings are not sufficient for a thorough comprehension of interactions between festival tourists. This exploratory study aims to contribute theoretically to tourism destination marketing research and specifically to the study of TTI in festival settings. Grounded theory has been adopted to construct a conceptual model containing the content and classifications of specific interactive incidents as well as the mechanisms, including drivers and influence, of festival TTI. Practical implications for festival operators to improve tourist relationships have also been analyzed based on the conceptual model.

\subsection{Literature Review}

\subsubsection{Customer-to-Customer Interaction (CCI)}

In the mid-1970s, service management theory started to accommodate the reality that a customer's perception of service could be affected by the behavior of other customers [19]. Due to the nature of service encounter in the simultaneous presence of multiple customers, they have to share time, space or service utensils with others [20]. Customers are inevitably required to engage in interactions with one another. Empirical studies have found CCI to be a familiar feature in a wide variety of service settings [5] in which customers may affect other customers' perception of service indirectly by being part of the environment or more directly through specific interactions [8]. However, the literature on service quality has not given sufficient attention to all CCI aspects that may contribute to customer experiences [21].

There are varying terms and definitions of CCI from different perspectives. Derived initially from the servuction system model, the term "customer B" was used to represent the concept of other customers present in the service setting [22]. On this basis, more exact descriptions of CCI have been established form plenty of conceptual or empirical studies. Although there is not yet a unified definition of CCI, it mostly refers to face-to-face, direct interpersonal interactions between customers taking place in physical onsite service settings, distinguishing it from offsite CCI which often means word-of-mouth $[13,20,23,24]$. Different types of CCI also have been investigated. Grove and Fisk (1997) identified a two-category classification of CCI as protocol incidents and sociability incidents through the critical incident technique. Kim and Choi (2016) suggested three types of CCI: friend-interaction, neighboring customer-interaction, and audience-interaction [25]. Moura E Sá and Amorim (2017) put forward a typology based on two main axes-service delivery orientation and exchange orientation-resulting in four major CCI scenarios: casual, functional, staged, and deliberate [21]. Through a systematic literature review, Heinonen (2018) revealed 11 different types of CCI interaction: knowledge exchange, problem solving, collective meaning-making, community building, endorsement, recreation and spending time, disciplinary and protocol behavior, verbal misbehavior, physical misbehavior, and contextual misbehavior which was categorized into offering-focused and process-focused interactions [11]. 
Increasing evidence shows that CCI, driven by various individual and environmental elements, greatly impacts customer experience perception as well as the value creation process. Behaviors originate from environment no matter physical or social aspects. Thus, CCI highly depends on servicescape - the majority of the physical environment which can promote the nature and the quality of interactions among customers by providing space for them to meet and talk [26-28]. The social aspects of the environment, known as social servicescape, include the mere presence of individuals as well as their behavior and can fundamentally affect CCI $[25,29]$. In addition to the environment, many studies acknowledge that customers' social motivations, such as to engage in social interaction, and to gain social status and a sense of affinity, are key drivers of CCI [11]. Moreover, researchers have investigated the effects of CCI on multiple service outcomes including purchase behavior, satisfaction, loyalty to the firm, word-of-mouth, and perceived service quality $[24,28,30,31]$.

\subsubsection{Tourist-to-Tourist Interaction (TTI)}

The shared beliefs, behavior and interactions with one another generate perceived emotional closeness between individuals including bother residents and tourists [32]. In contrast to the wide examinations of the relationships between residents and tourists under the framework of social exchange theory, tourist gaze and emotional solidarity [32-37], relationships among tourists have been relatively ignored due to its uncontrollable features. A few studies have drawn attention to the interactions between tourists on the basis of CCI. However, the mode, content, and depth of TTI are not fully appropriate for CCI because of the relatively longer period and hedonic nature of tourism activities [38]. Moreover, TTI in various tourism settings, including cruising [9,39,40], backpacking [41-43] and group tours [10,12], have been discussed by scholars, while TTI at festivals are really overlooked.

Distinct from service contexts in retail, passenger transportation, and education where CCI commonly occurs, social interactions between tourists construct the core part of tourism experience. As tourism is inherently a social phenomenon [40], the presence of fellow tourists is not only unavoidable but also indispensable in situations such as cruise ship travel, group tours, holiday resort stays, and festivals in which tourists have to share a confined environment and significant time with others [44]. Moreover, social motivations appear to be principal reasons for TTI in tourism settings which often provide a means for people with similar interests or motives to come together and interact [7].

Besides Lin (2019) focused on the single type of TTI, namely the self-disclosure which has been identified as the core factor of relationship between individuals [38], researchers have employed both qualitative and quantitative methods to classify different types of TTI. Using the critical incident technique, Harris and Reynolds (2004) revealed eight fundamental types of jaycustomers: compensation letter writers, undesirable customers, property abusers, service workers, vindictive customers, oral abusers, physical abusers, and sexual predators, predominantly ranging from financial gain to obtaining non-financial and personal benefits in hospitality industry [45]. Bosio and Lewis (2008) classified interactions between hotel guests into three broad categories: the exchange of greetings and pleasantries, engaging in mutual moans, and offering physical and informational assistance [46]. The principal components analysis of data from foreign travelers suggested that the perception of CCI incidents could be separated into six types: protocol and sociable incidents, violent incidents, grungy incidents, malcontent incidents, crude incidents, and inconsiderate incidents [8,47]. However, recently more conceptual approaches have been used to develop theoretical categories. Following an inductive approach for analyzing data from focus group discussions of cruise communities, the varying levels of interactions were summarized into three scenarios: no interaction or superficial interaction with negligible impact, spontaneous interactions that became an autotelic part of the cruise experience, and close interactions with lasting relationships that became one of the highlights of the cruise experience [9]. From the perspective of social constructivism, Reichenberger (2017) adopted social situation analysis in order to understand social interactions with other visitors and classified them 
into three levels of interaction: communitas level, social bubble level, and detached tourist level interactions [14]. Koenig (2018) investigated interactions between football spectators and classified them as two types-between known/familiar others, and between unknown-others [16]. Based on a large sample of tourists at Shanghai Disneyland, interactions between tourists were divided into positive and negative dimensions which significantly affected customer responses [48].

TTI is mostly driven by individual and environmental stimuli, as is CCI in service situations. Levy (2010) revealed that social motivations appear to be principal reasons for TTI in hedonic service settings including entertainment, arts, and leisure experiences [7]. Backpackers are mainly motivated to interact with others so as to gather information on destinations/businesses [43]. Cruise customers require distinct types of social interaction and the forging of new relationships due to the natural progression of TTI [9]. Additionally, individual characteristics such as values and mood, demographics, the level of personal interest and involvement, and the willingness and ability of individuals to respond to requests for product-related information, also drive TTI $[49,50]$. Other causal conditions for TTI are the physical and social environments. It is well-documented that the physical setting as external stimuli or "servicescape" can fundamentally influence social interactions between tourists $[17,41,46]$. Social aspects of environment such as the number of other tourists [10,41], physical proximity within the tour [40], social structure within the group [14], and perceived similarity with others [17] also contribute to TTI.

\section{Methodology}

\subsection{Research Design}

This study aims to investigate, in depth, the nature and formation mechanism of festival TTI, rather than form a universal theory applicable to all tourism contexts. It employs grounded theory for data collection, analysis, and theory formation. Grounded theory is an iterative, comparative, interactive, and abductive method formulated in the 1960s by Glaser and Strauss. Since then, three main versions of grounded theory have emerged: objectivist, post-positivist, and constructivist. In the constructivist version, used in this study, the investigative process emerges from interactions, data production and analysis are socially constructed, and the research goal is to enhance contextualized understanding [51]. As TTI is constructed within particular social contexts, a constructivist orientation to grounded theory should generate theoretical insights about festival participants' interactions.

\subsection{Data Collection}

\subsubsection{Case Study: Midi Music Festival}

The Midi Music Festival (Midi) originated from the underground rock music scene and has grown to pioneer the music festival industry in China. Midi has been considered the Chinese "Woodstock" as it contains many western festival characteristics (e.g., rock and pop music, outdoors, camping, alcohol) [52]. Midi is the largest and longest-running non-government music festival in mainland China; from its inception on 30 April 2000, to the end of 2018, it has been held 44 times. Nearly 100 national and international musical bands perform at each event. The Midi outdoor venue is mainly divided into performance and camping areas. In addition to live shows in the performance area, there are also various activities such as rock climbing, skateboarding, live Counter-Strike and flea markets. The camping area provides space for tourists to camp, rest, entertain, and communicate with others. Therefore, the scale of the festival, the sharing of time and space by music enthusiasts, and the diverse activities all offer a wide range of interactive opportunities. Midi provides a typical case for studying interactions between festival tourists, and allows sufficient observation space for in-depth research. 


\subsubsection{Sampling Selection and Interviews}

Interview data were collected from a total of 16 participants attending one of three Midi festivals: the Taihu Midi Music Festival from April 30 to 3 May 2016, the Tenglongdong Midi Music Festival from 15-17 September 2016, or the Shenzhen New Year Midi Music Festival from 31 December 2016 to 2 January 2017. Semi-structured interviews were used to obtain qualitative data. Each interview was recorded in full and subsequently transcribed.

Initially, after entering the Taihu Midi Music Festival, convenience sampling was used to identify individuals who had previously attended the Midi and were willing to be interviewed. Then the following 7 participants were identified using snowball sampling. Corbin and Strauss (1990) suggested that interviews should take place at locations and in situations that provide the greatest opportunity to gather the most relevant data about the phenomena under investigation [53]. Thus, interviews were generally conducted in the camping and rest areas near the performance stages.

In grounded theory, the analysis begins as soon as data is collected [53]. Data should be analyzed in a timely manner after each interview in order to find the theoretical gap to be supplemented with data in the next investigative phase. However, each Midi festival usually lasted only two or three days. Therefore, data acquisition and analysis were not fully saturated in the field due to time constraints, and original sampling was not available for supplemental investigation. In theoretical sampling, new research participants or information are purposefully sought, based on the data analysis; people and cases are identified to further elaborate theoretical categories [51]. Therefore, during the 2016 Tenglongdong Midi Music Festival and the 2016/17 Shenzhen New Year's Midi Music Festival, 8 participants were selected to bridge the data gaps and verify the theoretical saturation. In total, there are 16 interviewees in this study (see Table 1).

Table 1. Participant Profiles.

\begin{tabular}{ccccc}
\hline Participant & Gender & Frequency of Midi Participation & Date & Place \\
\hline TH1 & Male & 1 & $5 / 3 / 2016$ & Taihu ${ }^{1}$ \\
TH2 & Female & 4 & $5 / 1 / 2016 /$ & Taihu \\
TH3 & Female & 4 & $5 / 1 / 2016$ & Taihu \\
TH4 & Male & 1 & $5 / 1 / 2016$ & Taihu \\
TH5 & Male & 2 & $5 / 2 / 2016$ & Taihu \\
TH6 & Female & 3 & $5 / 2 / 2016$ & Taihu \\
TH7 & Male & 2 & $5 / 2 / 2016$ & Taihu \\
TH8 & Female & 1 & $5 / 3 / 2016$ & Taihu \\
TLD1 & Male & 1 & $9 / 16 / 2016$ & Tenglongdong \\
TLD2 & Male & 1 & $9 / 16 / 2016$ & Tenglongdong \\
TLD3 & Male & $>5$ & $9 / 17 / 2016$ & Tenglongdong \\
TLD4 & Male & 4 & $9 / 17 / 2016$ & Tenglongdong \\
TLD5 & Female & 2 & $9 / 17 / 2016$ & Tenglongdong \\
SZ1 & Female & 1 & $1 / 1 / 2017$ & Shenzhen Center ${ }^{3}$ \\
SZ2 & Male & 2 & $1 / 1 / 2017$ & Shenzhen Center \\
SZ3 & Male & 2 & $1 / 2 / 2017$ & Shenzhen Center \\
\hline
\end{tabular}

${ }^{1}$ Taihu $=$ Taihu MIDI Camp,${ }^{2}$ Tenglongdong $=$ Tenglongdong Scenic Area,${ }^{3}$ Shenzhen $=$ Shenzhen Universiade.

\subsection{Data Analysis}

Grounded theory research procedures continuously compare, think, analyze, and transform data into concepts to establish a theory. The data analysis, or coding is the core link. In grounded theory research, there are three basic types of coding: open, axial, and selective [53].

Open coding is the interpretive process of decomposing, examining, comparing, conceptualizing, and categorizing data. Its purpose is to give the analyst insights by breaking through standard ways of thinking about or interpreting phenomena reflected in the data. In open coding, events/actions/interactions are compared with others for similarities and differences. They are also given conceptual labels. First, 
we analyzed the data word by word, extracting relevant concepts, and merging those with overlapping meanings. Then, concepts of similar incidents were gathered to further abstract the initial categories. Through the analysis of the original data, 372 initial concepts were obtained. Further, 33 preliminary categories were formed by summarizing and refining the initial concepts. Table 2 shows examples of the initial concepts and preliminary categories obtained from open coding.

Table 2. Open coding of tourist-to-tourist interaction (TTI) (excerpt).

\begin{tabular}{lcc}
\multicolumn{1}{c}{ Original Data } & Labeling & Preliminary Categories \\
\hline $\begin{array}{l}\text { It was easier to get excited when in the crowd. They were } \\
\text { interactively playing pogo or wall of death in the crowd. }\end{array}$ & In the crowd \\
The more crowded, the happier we were. & \\
\hline $\begin{array}{l}\text { Because it was my favorite band, I pushed forward to get into } \\
\text { the front rows. I remembered that I finally got into the second } \\
\text { row. It was so cool. }\end{array}$ & In the front rows & Spatial locations \\
$\begin{array}{l}\text { I just wanted to sit away from the stages to quietly watch } \\
\text { the show, even during the performance of my favorite band. }\end{array}$ & Far away from the stages \\
$\begin{array}{l}\text { I wouldn't push into the crowd. } \\
\begin{array}{l}\text { I just came from another stage when WanQing (name of } \\
\text { a music band) was performing. I was too tired to get into } \\
\text { the crowd. I held a bottle of beer and stood behind the crowd. }\end{array}\end{array}$ & Behind the crowd \\
\hline
\end{tabular}

Axial coding refers to the process of developing main categories and their subcategories [54]. Through the "coding paradigm" of conditions, context, strategies (action/interaction), and consequences, subcategories are related to a category [53]. On the basis of situational understanding, six main categories were developed. Table 3 shows the main categories, their conceptualizations, and dimensions.

Table 3. Axial coding of tourist to tourist interaction.

\begin{tabular}{|c|c|c|}
\hline Main Category & Conceptualization & Dimension \\
\hline \multirow{3}{*}{ Festivalscape } & Weather & Rainy, cloudy, sunny \\
\hline & Layout & $\begin{array}{c}\text { Performance area, functional area, stages, camping area, } \\
\text { viewing area }\end{array}$ \\
\hline & Music style & Heavy metal, folk, punk, blues, electronic music \\
\hline \multirow{3}{*}{ Social festivalscape } & Crowd density & Crowded-few people \\
\hline & Emotions of other tourists & Happy-unhappy, calm-crazy \\
\hline & Behavior of other tourists & $\begin{array}{c}\text { Jumping, wall of death, scream, circle pit, waving hand in } \\
\text { hand, driving a train }\end{array}$ \\
\hline \multirow{4}{*}{$\begin{array}{c}\text { Individual } \\
\text { Characteristics }\end{array}$} & Personality characteristics & Introversion-extroversion, sentimental-calmness \\
\hline & Musical preferences & Heavy metal, folk, punk, blues, electronic music \\
\hline & $\begin{array}{l}\text { Previous experiences } \\
\text { of music festival }\end{array}$ & First-time, goer-frequenter \\
\hline & Motivations & Meeting friends, escaping from daily life, relaxing \\
\hline \multirow{3}{*}{$\begin{array}{l}\text { Tourist-to-tourist } \\
\text { interaction }\end{array}$} & Entertainment & $\begin{array}{l}\text { Pogo, wall of death, driving a train, } \\
\text { singing together, jumping }\end{array}$ \\
\hline & Mutual assistance behavior & $\begin{array}{l}\text { Holding items for others, protecting others, searching for } \\
\text { lost items, providing information }\end{array}$ \\
\hline & Conflict & Pushing and squeezing, fighting, arguing \\
\hline \multicolumn{2}{|c|}{ Evaluation of overall experience } & $\begin{array}{l}\text { Crazy, beautiful, boisterous, grand, memorable, immersed, } \\
\text { satisfied, shocked }\end{array}$ \\
\hline \multicolumn{2}{|c|}{ Locations } & $\begin{array}{c}\text { In the crowd, in the front rows, behind the crowd, far away } \\
\text { from the stages }\end{array}$ \\
\hline
\end{tabular}


Selective coding is the process by which all categories are unified around a "core" category, and categories that need further explication are filled-in with descriptive detail. The core category represents the central phenomenon studied [53]. Selective coding was used to specify possible relationships between these categories and to form an initial theoretical framework. Finally, a model was developed after revisiting the coded and categorized statements and identifying their inter-relationships.

\section{Findings}

\subsection{Types of Tourist-to-Tourist Interaction (TTI)}

In the festival context, the interactive behaviors of tourists were divided into three types: entertainment, mutual assistance, and conflict.

\subsubsection{Entertainment}

The entertainment interactions around the musical theme constitute the central part of the festival experience. The most important features of outdoor music festival are the variety of interactive activities that participants may engage in during the shows. In the performance area, "you can play together with others at the live show" (TH6). "For example, you can play pogo, jumping, driving a train, or wall of death" (TH1). Some festival-goers were motivated by recreational interactions with others, so music enjoyment was less important. These entertainment activities allowed festival attendees to release daily life pressures and escape from the real world.

As a "continuation of the live shows," the camping area is the stage spontaneously generated by tourists themselves. As rock music has always been on the fringe of the cultural mainstream in mainland China, rock music fans can feel isolated in real life. Midi, especially the camping area, provides them with the opportunity to "play with a group of like-minded people for a few days." Therefore, compared with the full input in the performance area, the entertainment interaction in the camping area is more like a carnival with friends. Through drinking, chatting, playing the guitar, singing together, as well as other interactions, strong affective links are established between tourists, as well as a sense of belonging, which is scarce in daily life.

"Camping is an indispensable part of Midi. After the showtime in the performance area, we are playing, singing, drinking and doing everything we like to in the camping area. Just now a group of people are playing pogo when waiting for the outdoor show" (TH5).

\subsubsection{Mutual Assistance Behavior}

Mutual assistance behavior is an important type of interactions between festival tourists. Individuals as social network links often possess multiple social identities in daily life. The existence of social identities can influence decision-making behavior and even force individuals into herd behavior for a sense of belonging. At Midi, tourists are immersed in the state of authentic "me" shedding the "we" and "us" of daily routine, and are able to "remove some defenses and masks, and show the authentic ego to outsiders" (TLD3). Therefore, during the liminal music festival experience, the "true self" with a good heart and integrity is more likely presented, and thus it is easier for tourists to assume assistance-providing roles.

Mutual assistance behaviors between tourists mainly include holding someone who was going to fall in the crowd; holding other tourists' personal belongings while they participated in more intense physical interactions; and helping first-time event goers integrate into the festival atmosphere. These spontaneous mutual assistance behaviors help tourists gain trust and generate relationships, which facilitates the formation of a memorable experience.

"Because there is a lot of fresh blood coming to Midi every year, I want to help everyone to play together and inherit the essence of traditional culture of Midi. In fact, I feel even happier when helping others than playing alone" (TH3). 


\subsubsection{Conflict}

Individual differences, especially motivations for festival attendance and musical preferences, inevitably lead to conflicts among tourists. Different stages usually focus on different music styles, so participants with different preferences are moderately distinguished. For example, the Zhanguo stage usually focuses on heavy metal music, while the Ming stage focuses on folk music, post-shake, and other relatively light music styles. However, as a comprehensive main stage, the Tang stage usually has various shows with differing styles, which indirectly triggers conflicts, such as shoving and crowding among tourists. In the more intense interactive activities, such as wall of death, there are inevitably some physical conflicts between participants. In the camping area, uncivilized behaviors such as drunkenness, smoking, and loud noises are more likely to cause dissatisfaction and even conflict.

"I was tired when I went back to the tent last night and I went to sleep. Later, it seemed that the people in the Ye group had been drunk and harassed the tents one by one. I was quarreling with them at that time" (TLD2).

\subsection{Drivers of TTI}

Both individual and environmental factors affect interactions between festival tourists. The individual characteristics are the internal driving factors, including personality characteristics, musical preferences, participation experience, and motivations. The impact of the environment can be divided into two aspects: the festivalscape and the social festivalscape.

\subsubsection{Individual Characteristics}

Personalities are the most influential elements of individual behavior. Extroverted tourists are more likely to get into the surrounding environment and be affected by the emotions or behaviors of others. As TH8 noted, "It should be easier for more outgoing people to get excited, to communicate with others, to interact with others and to express themselves". However, tourists who are more introverted are less likely to be affected by others' emotions and surrender themselves to the festivities.

Motivation is the intrinsic driver for individuals to adopt corresponding behavioral strategies. Therefore, tourists engage in different types of interactions according to their motivations. Those who just want to "listen to their favorite music" pay more attention to the music itself and "don't want to play with other tourists." Others consider interacting with friends crucial to the festival experience. TLD3 noted, "I came to Midi because I wanted to get together with my friends across the country and to drink, talk and chat with them by taking the advantage of this opportunity".

Musical preference is highly personal. Although the main style of the Midi is based on rock, bands with styles are invited, such as folk, rap, and pop. Therefore, festival-goers behave according to their own preferences. Especially when encountering the performance of one's favorite band, tourists tend to fully invest emotionally. As TH1 noted, "When I watched the show of Mirror, I was in the first row. Because I have been enchanted with them for a longtime, the show really touched me. I can sing along with them for every song. It was so cool and happy". Conversely, when individuals experienced some music styles that differed from their preferences, their participation was limited. TLD2 noted, "Because I am still a calm person, I think heavy metal is a bit noisy and unacceptable to some extent. I didn't play with them when watching the heavy metal bands".

Another individual factor is previous experience at music festivals, especially the Midi. There were significant differences in interactions between first-time goers and the frequent participants. Generally speaking, the Midi is completely different from daily life for first-time goers. They were more "curious and fresh" and as TH4 noted "various places to visit with all kinds of music worth listening to". Therefore, first-timers were more enthusiastic about participating in interactive activities. Experienced participants were more likely to feel bored with the usual interactive activities.

"I am almost tired of coming to Midi. I have been here nearly six or seven times. I don't have the feeling of surprise any more in here. At first when I came to Midi, I used to go to play pogo, 
jumping and other activities. But it's not going to happen now. I'm too lazy to squeeze inside. I'm too tired to stand behind the crowd" (TLD4).

\subsubsection{Environmental Impacts}

The impacts of the environment can be divided into two aspects: festivalscape and social festivalscape. Festivalscape is the overall perception of the environmental stimuli in festival situations, which shape and influence tourists' general experience. The Festivalscape of the Midi mainly includes musical performances, weather conditions, and the spatial layout. Music is a core element of the Midi. Performances of different music styles decisively influence interactive activities between tourists. As TH7 noted, "For example, everyone must be quiet when listening to folk music and sing together when the music climaxes. If someone holds a gesture of metal music during punk shows, there would be some problems. Besides we play pogo, jumping and wall of death in shows of punk and metal. That is to say each specific music styles relates to specific gameplay".

Weather conditions also affect the willingness and involvement of TTI. Since the Midi is outdoors, activities are limited by weather conditions. On sunny or cloudy days, there is more participation and enthusiasm for on-site interactions. If it rains (absent a downpour), shows continue, but with "fewer participants who are much lazier to interact under the stage" (TH1). Moreover, rainy days also have a greater impact on TTI in the camping area. Since the campsite is generally a relatively flat grassy area, it becomes wet and muddy with rain. Thus, most tourists choose to go to nearby hotels and those who stay in the campsite generally remain in their tents.

TTI is also affected by the festival spatial layout, such as the space between stages, location of audience areas, distribution of entertainment facilities, and architectural style. Stage layout affects the spatial flow of participants. For example, "The Zhanguo stage and Tang stage are too far away. I am too lazy to run around" (TLD1). The layout of the audience area in front of the stage also limits interactive activities. The Zhanguo stage is dominated by heavy rock music performance. Therefore, tourists generally carry out more intense interactions such as wall of death, but "the venue is too small and crowded to hold so many people" (TH8). Additionally, the architectural style within the venue also impacts TTI.

“The Taihu Midi Camp has a feeling of conflict with rock music culture. It is too delicate and makes us feel that it is somewhat out of place. If it is more open and rougher, we may play much happier and crazier" (TH6).

The social festivalscape is the perception of social environmental variables, including crowd density and the emotions and behaviors of others. In other consumption situations, higher crowd density tends to diminish the overall experience. However, in festival settings such as Midi, crowds provide interactive opportunities between tourists and help generate more positive experiences. As TH8 noted, "It's quite crowded in front of the stage. But I like this feel. I don't like it when there are few people at the festival. If the distance between us is too far, there would be a lack of such an atmosphere. Interactive activities such as jumping, wall of death and driving a train are hard to be developed when there are few people under the stage".

The representation of others' emotions and behaviors are also important social environmental factors. Strong emotions are infectious in tourists, although emotional involvement varies significantly due to individual differences. Those who are more passive or introverted interact more easily when others are highly emotionally and behaviorally engaged in the atmosphere.

"As long as there is one person starting to play, surrounding people follow to play together. When the atmosphere is intense, all participants are involved. Everyone is emotionally engaged" (SZ1).

\subsection{TTI Locations}

Spatial impacts neglected in previous studies have essential effects on TTI. Individuals, propelled by internal factors, choose their spatial locations during the music shows. The experience of the Midi significantly varies from the micro-environment of different spatial locations which influences 
the perception of physical and social environmental factors. Thus, interactions in different locations are affected by the density and the involvement level of surrounding tourists. The formation of interactive activities such as jumping, driving a train, and wall of death requires a crowd; crowd density intensifies participants' excitement. Therefore, such interactions often occur in front of the stages and in the center of the crowd. When away from the stage and the crowd, TTI tends to be low-intensity, such as pogo and hand-in-hand singing together.

"I felt that it was more exciting and much easier to integrate into the music atmosphere when standing in the crowd. And the closer you were to the performing bands, the more infected you would get. Other surroundings could strongly drive you to engage in the interactive activities when you were in the heart of the crowd" (TLD5).

\subsection{Influence of TTI}

TTI occurs throughout the festival, in both time and space. Participants' perception of the quality of interaction is closely linked to their evaluation of the overall Midi experience. Positive interactions enhance emotions and cognition about the experience. High-quality musical interactions between tourists help generate positive performance evaluations. Additionally, socialization is the main motivator for some, especially first-time attendees unfamiliar with the live bands. Despite the unfamiliarity, TTI promotes integration into the overall interactive atmosphere with the assistance of others and thus produces a profound experience.

“Though I don't know them, I felt that the overall atmosphere of the band was really amazing. People from the first row to the last row were entirely infected with music and dancing around. They were hand in hand and playing pogo. Midi is fantastic and crazy. I really love it" (TH8).

\section{Discussion}

Using grounded theory, this study constructed a conceptual model of TTI, shown in Figure 1. This model shows the main categories of social interaction between tourists, its formation process, as well as its influence. The figure shows TTI is the core of the model and there are three types of interactions: entertainment, mutual assistance, and conflict. Additionally, factors that influence interactions between tourists include individual and environmental aspects. Individual characteristics are personality, musical preferences, previous experience of music festivals and motivations. The environmental influences are divided into festivalscape and social festivalscape. Additionally, locations of tourists in the festival venue can directly influence TTI and indirectly influence TTI through its impacts on festivalscape and social festivalscape perceptions. Finally, the evaluation of overall experience is influenced by all factors, especially TTI.

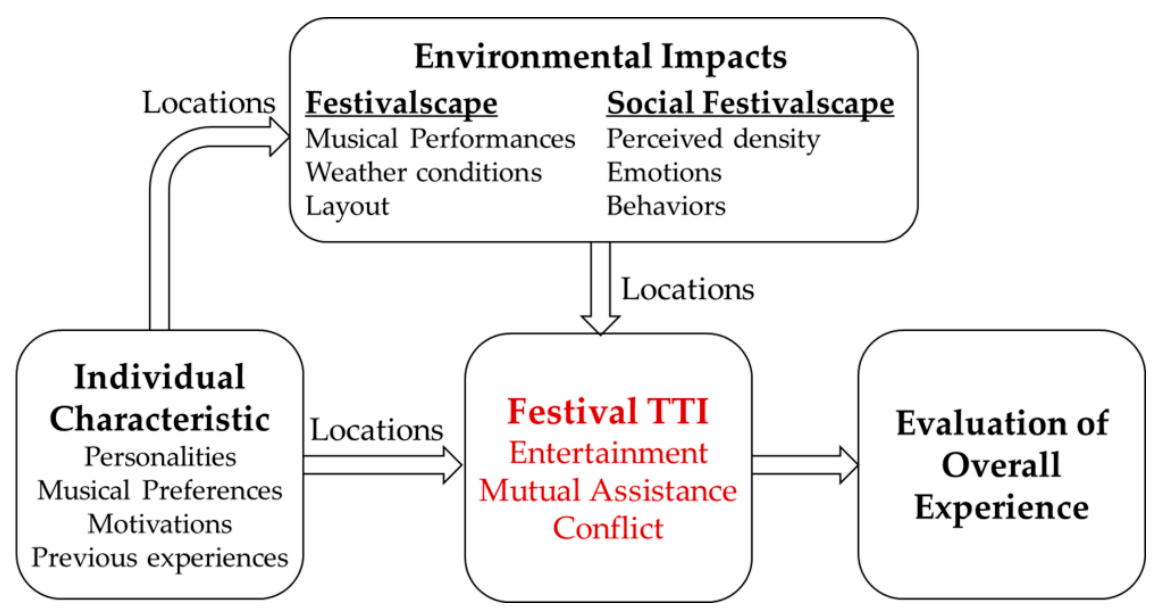

Figure 1. Conceptual model of festival tourist-to-tourist interaction (TTI). 
Social interactions between tourists have been highlighted in previous studies [55], in which entertainment TTI has been neglected. Entertainment interaction is the crucial type of TTI at festivals. Music festivals are typical hedonic services which consist entertainment as principle feature [7] and many festival-goers are primarily motivated by interactive recreational activities. Previously, mutual assistance behaviors and conflict have been emphasized. In many service settings, customers interact with each other by providing instructions or assistance [21]. Stemming from a variety of product knowledge, personality, and motives, different tourists may take on different roles, including reactive helper or helpseeker, or proactive helper or helpseeker [8]. However, first-time festival goers always seek information and physical assistance from frequent goers to facilitate engagement in the overall atmosphere. Moreover, Martin and Pranter (1989) revealed that incompatible behaviors could give rise to customer dissatisfaction [56]. Since then, conflicts and their impacts among tourists have been highlighted in the literature [41].

TTI is propelled by both endogenous and exogenous effects. Endogenous effects are personality characteristics, music style preference, participation experience, and motivations. Exogenous effects refer to environmental features of both festivalscape and social festivalscape. Differences in specific classifications aside, most researchers agree that both individual characteristics and environmental settings contribute to more profoundly perceived social interactions [14]. Extroverted tourists are more social and talkative [17] during festivals. Besides, social motivations appear to be principal reasons for interaction in hedonic service settings such as festival tourism. Festival-goers desire to make social bonds with fellow tourists for identification and shared interests [11,43,49]. However, both musical preferences and previous participation experiences can significantly influence TTI and have not received enough attention in previous studies. Music style preference mainly affects the types of interactions, while the participation experience has great impact on the involvement of tourists' interpersonal interactions.

Physical and social environmental factors also affect interactions between tourists. The festivalscape, the venue itself and the physical environment surrounding the festival [57], can facilitate TTI by providing space for tourists to meet and engage $[27,58]$. Compared with the physical aspects, social festivalscape has a more significant impact on tourists' behavior [59]. The behaviors and experiences of tourists are influenced simultaneously by the presence of others and perceptions of other tourists' emotions and behavior in the festival setting.

The spatial locations occupied by tourists or the distance from the crowd when interacting with others in festival space play important mediating effects. Outdoor music festival tourists are relatively free to select and change locations. It is known that spaces conducive to social interaction may be one of the primary meanings of the tourism experience [60]. Furthermore, locations determine the spatial framework for environmental factors. At different distances, the information perceived by the senses differs. For example, in close proximity, contact is feasible, while vision and hearing become more important at greater distances. Thus, tourists change their interactive behaviors according to the distance they are separated [61]. Most festival-goers seek close proximity with other tourists because interactions between festival participants are key motivators. Hence, dense crowds give the sense of belonging and the social contact sought; this is in contrast with the dissatisfaction that crowd density brings to customers in general service situations [62].

TTI is a strong predictor of evaluation of festival experience which is a holistic concept including both cognitive and emotional aspects. Social interactions between tourists are an essential part of the festival experience [49]. Perceptions of TTI directly or indirectly influence tourists' holistic experience [44,47].

\section{Conclusions}

This exploratory study contributes to the comprehensive understanding of TTI in festival settings. A grounded theory approach using interview data was applied to construct a conceptual model of TTI. The model revealed types of TTI (entertainment behavior, mutual assistance, and conflict), 
drivers and influence of social interactions between festival tourists. The festival specifics are reflected in the participants' keen attention to recreational involvement. Thus, entertainment activities compose the major part of social interactions between tourists, due to the hedonic nature of festival tourism. Furthermore, drivers of TTI are both internal and external to participants. Internal drivers include personality characteristics, musical preferences, previous participation experience, and motivations. Environmental aspects include festivalscape and social parts of environment or the social festivalscape. The significant influence of locations or proximity to other tourists on social interactions was highlighted. Location preferences stemming from individual characteristics directly influence interpersonal interactive behaviors between festival-goers and have an indirect impact on TTI. Additionally, both positive and negative interactions between tourists affected the overall evaluation of festival experience.

This study offers certain actionable implications for festival managers to improve tourists' experiences as well as to remain competitive in the market. Specifically, managers can design various entertainment activities during the festival. Because entertainment incidents construct the essential part of on-site interactions, festival staff can shape the atmosphere to encourage tourists to engage in interactive entertainment with others around them. By formulating behavioral norms, managers can limit undesirable behaviors so as to avoid conflict as much as possible. Furthermore, the festival layout such as stage, resting areas, and service areas, should be planned to provide opportunities for tourists to interact. Managers should provide tourists with a shared space that is accessible and facilitates interaction.

This study has some limitations. A qualitative method was applied for theory formation to gain a deep understanding of festival TTI. However, the relationships between constructs in the conceptual model need to be further examined through quantitative research. Scales for constructs should be developed on the basis of this study's qualitative findings. In particular, the measurement of TTI should be assessed for various types of festivals to ensure its reliability. The mediating effect of locations, which has previously been neglected, should also be assessed through further research. Additionally, the direct impact of TTI on evaluation of festival experience has been investigated in this research, while the indirect influence on behavior factors (including satisfaction, revisit intention and word-of-mouth) which have been revealed in previously literatures, has not been taken into account. Further studies need to contain tourist behavior variables into a broader framework in order to reveal the indirect effects of festival TTI.

The generalizability of findings is limited because original data were collected solely from tourists at the Midi Music Festival, and festival TTI is profoundly affected by physical and social environmental features, which vary across different types of festivals [63]. Specifically, the content of particular festival variables generates different types of interactions. The classification of TTI in the conceptual model was thus derived from the analysis of Midi. Therefore, future research should include more extensive settings of festivals to discuss TTI in order to enrich the model.

Since on-site social interactions between tourists have been demonstrated, the procession of data collection was completely finished on-scene at Midi, where in-depth interviews could be conducted only while waiting for the performance opening and during the halftime interval. The sample size of this study was thus quite limited for the 2-3 days of the festival. Longer festivals could be investigated in order to gain a larger sample size in the future. In addition, increasing the number of people conducting interviews could boost the number of participants interviewed, even during short festivals.

Author Contributions: Conceptualization, H.S.; Data curation, H.S.; Formal analysis, H.S., S.W. and Y.L.; Investigation, S.W.; Methodology, H.S.; Resources, G.D.; Writing—original draft, H.S.; Writing—review and editing, H.S., Y.L. and G.D.

Funding: This research was funded by the National Natural Science Foundation of China (grant number 41571132) and the National Social Science Foundation of China (grant number 17XMZ028).

Conflicts of Interest: The authors declare no conflict of interest. 


\section{References}

1. Martínez, T.L.; Toledo, L.D.; Faraoni, N. Auditing Marketing and the Use of Social Media at Ski Resorts. Sustainability 2019, 11, 2868. [CrossRef]

2. Bruwer, J.; Kelley, K. Service performance quality evaluation and satisfaction in a USA wine festivalscape. Int. J. Event Festiv. Manag. 2015, 6, 18-38. [CrossRef]

3. Malchrowicz-Mośko, E.; Chlebosz, K. Sport Spectator Consumption and Sustainable Management of Sport Event Tourism; Fan Motivation in High Performance Sport and Non-Elite Sport. A Case Study of Horseback Riding and Running: A Comparative Analysis. Sustainability 2019, 11, 2178. [CrossRef]

4. Pegg, S.; Patterson, I. Rethinking Music Festivals as a Staged Event: Gaining Insights from Understanding Visitor Motivations and the Experiences They Seek. J. Conv. Event Tour. 2010, 11, 85-99. [CrossRef]

5. Nicholls, R. New directions for customer-to-customer interaction research. J. Serv. Mark. 2010, $24,87-97$. [CrossRef]

6. Jung, J.H.; Yoo, J.J.; Arnold, T.J. Service Climate as a Moderator of the Effects of Customer-to-Customer Interactions on Customer Support and Service Quality. J. Serv. Res. 2017, 20, 426-440. [CrossRef]

7. Levy, S.E. The hospitality of the host: A cross-cultural examination of managerially facilitated consumer-to-consumer interactions. Int. J. Hosp. Manag. 2010, 29, 319-327. [CrossRef]

8. Wu, C.H.-J. The influence of customer-to-customer interactions and role typology on customer reaction. Serv. Ind. J. 2008, 28, 1501-1513. [CrossRef]

9. Huang, J.; Hsu, C.H.C. Interaction among fellow cruise passengers: Diverse experiences and impacts. J. Travel Tour. Mark. 2009, 26, 547-567. [CrossRef]

10. Pearce, P.L. Tourist Behaviour: Themes and Conceptual Schemes; Channel View Publications: Clevedon, UK, 2005.

11. Heinonen, K.; Jaakkola, E.; Neganova, I. Drivers, types and value outcomes of customer-to-customer interaction: An integrative review and research agenda. J. Serv. Theor. Pract. 2018, 28, 710-732. [CrossRef]

12. Torres, E.N. The Influence of Others on the Vacation Experience: An Ethnographic Study of Psychographics, Decision Making, and Group Dynamics among Young Travelers. J. Hosp. Mark. Manag. 2015, 24, 1-31. [CrossRef]

13. Rahman, K.; Karpen, I.O.; Reid, M.; Yuksel, U. Customer-to-customer interactions and word of mouth: Conceptual extensions and empirical investigations. J. Strat. Mark. 2015, 23, 287-304. [CrossRef]

14. Reichenberger, I. C2C value co-creation through social interactions in tourism. Int. J. Tour. Res. 2017, 19, 629-638. [CrossRef]

15. Rihova, I.; Buhalis, D.; Moital, M.; Gouthro, M. Conceptualising customer-to-customer value co-creation in tourism. Int. J. Tour. Res. 2015, 17, 356-363. [CrossRef]

16. Koenig-Lewis, N.; Asaad, Y.; Palmer, A. Sports events and interaction among spectators: Examining antecedents of spectators' value creation. Eur. Sport Manag. Q. 2018, 18, 193-215. [CrossRef]

17. Zgolli, S.; Zaiem, I. Customer-to-customer interaction in tourism experience: Moderating role of nationality. Arab. Econ. Bus. J. 2017, 12, 44-56. [CrossRef]

18. Chang, M.; Kim, J.-H.; Kim, D. The Effect of Food Tourism Behavior on Food Festival Visitor's Revisit Intention. Sustainability 2018, 10, 3534. [CrossRef]

19. Nicholls, R. Customer-to-customer interaction (CCI): A cross-cultural perspective. Int. J. Contemp. Hosp. Manag. 2011, 23, 209-223. [CrossRef]

20. Baron, S.; Patterson, A.; Harris, K.; Hodgson, J.; Cassidy, K. Strangers in the night: Speeddating, CCI and service businesses. Serv. Bus. 2007, 1, 211-232. [CrossRef]

21. Moura, E.; Sá, P.M.; Amorim, M. A typology of customer-to-customer interaction and its implications for excellence in service provision. Total Qual. Manag. Bus. Excel. 2017, 84,1-11. [CrossRef]

22. Nicholls, R.; Mohsen, M.G. Other customer age: Exploring customer age-difference related CCI. J. Serv. Mark. 2015, 29, 255-267. [CrossRef]

23. McGrath, M.A.; Otnes, C. Unacquainted influencers: When strangers interact in the retail setting. J. Bus. Res. 1995, 32, 261-272. [CrossRef]

24. Niloofar, I.; Meysam, F.; Sara, F. The effect of customer-to-customer interactions on satisfaction with the firm, loyalty to the firm and firm word-of-mouth: The case of Iran Air Company. Afr. J. Bus. Manag. 2012, 6, 10427-10437. [CrossRef] 
25. Kim, H.S.; Choi, B. The effects of three customer-to-customer interaction quality types on customer experience quality and citizenship behavior in mass service settings. J. Serv. Mark. 2016, 30, 384-397. [CrossRef]

26. Davies, B.; Baron, S.; Harris, K. Observable oral participation in the servuction system: Toward a content and process model. J. Bus. Res. 1999, 44, 47-53. [CrossRef]

27. Harris, K.; Baron, S.; Parker, C. Understanding the consumer experience: It's 'Good to Talk'. J. Mark. Manag. 2000, 16, 111-127. [CrossRef]

28. Tomazelli, J.; Broilo, P.L.; Espartel, L.B.; Basso, K. The effects of store environment elements on customer-to-customer interactions involving older shoppers. J. Serv. Mark. 2017, 31, 339-350. [CrossRef]

29. Libai, B.; Bolton, R.; Bügel, M.S.; Ruyter, K.; Götz, O.; Risselada, H.; Stephen, A.T. Customer-to-Customer interactions: Broadening the scope of word of mouth research. J. Serv. Res. 2010, 13, 267-282. [CrossRef]

30. Jung, J.H.; Yoo, J.J. Customer-to-customer interactions on customer citizenship behavior. Serv. Bus. 2017, 11, 117-139. [CrossRef]

31. Yoo, J.; Arnold, T.J.; Frankwick, G.L. Effects of positive customer-to-customer service interaction. J. Bus. Res. 2012, 65, 1313-1320. [CrossRef]

32. Woosnam, K.M.; Norman, W.C. Measuring residents' emotional solidarity with tourists: Scale development of Durkheim's theoretical constructs. J. Travel Res. 2010, 49, 365-380. [CrossRef]

33. Urry, J. The Tourist Gaze; Sage Publications: London, UK, 2002.

34. Woosnam, K.M. Comparing residents' and tourists' emotional solidarity with one another. J. Travel Res. 2011, 50, 615-626. [CrossRef]

35. Woosnam, K.M.; Aleshinloye, K.D. Residents' emotional solidarity with tourists: Explaining perceived impacts of a cultural heritage festival. J. Hosp. Tour. Res. 2018, 42, 587-605. [CrossRef]

36. Weaver, D.B.; Lawton, L.J. Resident perceptions of a contentious tourism event. Tour. Manag. 2013, 37, $165-175$. [CrossRef]

37. Wallace, R.A.; Wolf, A. Contemporary Sociological Theory: Expanding the Classical Tradition; Prentice Hall: New York, NY, USA, 2006.

38. Lin, H.; Zhang, M.; Gursoy, D.; Fu, X. Impact of tourist-to-tourist interaction on tourism experience: The mediating role of cohesion and intimacy. Ann. Tour. Res. 2019, 76, 153-167. [CrossRef]

39. Papathanassis, A. Guest-to-guest interaction on board cruise ships: Exploring social dynamics and the role of situational factors. Tour. Manag. 2012, 33, 1148-1158. [CrossRef]

40. Huang, J.; Hsu, C.H.C. The Impact of Customer-to-Customer interaction on cruise experience and vacation satisfaction. J. Travel Res. 2010, 49, 79-92. [CrossRef]

41. Yin, C.; Poon, P. The impact of other group members on tourists' travel experiences: A study of domestic package tours in China. Int. J. Contemp. Hosp. Manag. 2016, 28, 640-658. [CrossRef]

42. Sørensen, A. Backpacker ethnography. Ann. Tour. Res. 2003, 30, 847-867. [CrossRef]

43. Murphy, L. Exploring social interactions of backpackers. Ann. Tour. Res. 2001, 28, 50-67. [CrossRef]

44. Rihova, I.; Buhalis, D.; Gouthro, M.B.; Moital, M. Customer-to-customer co-creation practices in tourism: Lessons from Customer-Dominant logic. Tour. Manag. 2018, 67, 362-375. [CrossRef]

45. Reynolds, K.L.; Harris, L.C. Jaycustomer behavior: An exploration of types and motives in the hospitality industry. J. Serv. Mark. 2004, 18, 339-357.

46. Bosio, E.; Lewis, B. Customer-to-customer interactions: examining consumer behaviour in hotels in cyprus. Int. J. Manag. Cases 2008, 10, 345-354. [CrossRef]

47. Wu, C.H.-J. The impact of customer-to-customer interaction and customer homogeneity on customer satisfaction in tourism service-The service encounter prospective. Tour. Manag. 2007, 28, 1518-1528. [CrossRef]

48. Luo, J.G.; Wong, I.A.; King, B.; Liu, M.T.; Huang, G.Q. Co-creation and co-destruction of service quality through customer-to-customer interactions: Why prior experience matters. Int. J. Contemp. Hosp. Manag. 2019, 31, 1309-1329. [CrossRef]

49. Baron, S.; Harris, K. Consumer-to-Consumer Conversations in Service Settings. J. Serv. Res. 2004, 6, $287-303$.

50. Levy, S.E.; Getz, D.; Hudson, S. A Field Experimental Investigation of Managerially Facilitated Consumer-to-Consumer Interaction. J. Travel Tour. Mark. 2011, 28, 656-674. [CrossRef]

51. Matteucci, X.; Gnoth, J. Elaborating on grounded theory in tourism research. Ann. Tour. Res. 2017, 65, 49-59. [CrossRef] 
52. Li, Y.N.; Wood, E.H. Music festival motivation in China: Free the mind. Leis. Stud. 2016, 35, $332-351$. [CrossRef]

53. Corbin, J.M.; Strauss, A. Grounded theory research: Procedures, canons, and evaluative criteria. Qual. Sociol. 1990, 13, 3-21. [CrossRef]

54. Mehmetoglu, M.; Altinay, L. Examination of grounded theory analysis with an application to hospitality research. Int. J. Hosp. Manag. 2006, 25, 12-33. [CrossRef]

55. Grove, S.J.; Fisk, R.P. The impact of other customers on service experiences: A critical incident examination of "getting along". J. Retail. 1997, 73, 63-85. [CrossRef]

56. Martin, C.L.; Pranter, C.A. Compatibility Management: Customer-to-Customer Relationships in Service Environments. J. Serv. Mark. 1989, 3, 5-15. [CrossRef]

57. Lee, T.H.; Chang, P. Examining the relationships among festivalscape, experiences, and identity: Evidence from two Taiwanese aboriginal. Leis. Stud. 2017, 36, 1-15. [CrossRef]

58. Moore, M.L.; Capella, M.; Moore, R. The impact of customer-to-customer interactions in a high personal contact service setting. J. Serv. Mark. 2005, 19, 482-491. [CrossRef]

59. Jang, Y.; Ro, H.; Kim, T.-H. Social Servicescape: The Impact of Social Factors on Restaurant Image and Behavioral Intentions. Int. J. Hosp. Tour. Adm. 2015, 16, 290-309. [CrossRef]

60. Yarnal, C.M.; Kerstetter, D. Casting Off: An Exploration of Cruise Ship Space, Group Tour Behavior, and Social Interaction. J. Travel Res. 2016, 43, 368-379. [CrossRef]

61. Kendon, A. Conducting Interaction: Patterns of Behavior in Focused Encounters; Cambridge University Press: Cambridge, UK, 1990.

62. Tombs, A.G.; McColl-Kennedy, J.R. Social and spatial influence of customers on other customers in the social-servicescape. Australas. Mark. J. 2010, 18, 120-131. [CrossRef]

63. Yang, J.; Gu, Y.; Cen, J. Festival Tourists' Emotion, Perceived Value, and Behavioral Intentions: A Test of the Moderating Effect of Festivalscape. J. Conv. Event Tour. 2011, 12, 25-44. [CrossRef]

(C) 2019 by the authors. Licensee MDPI, Basel, Switzerland. This article is an open access article distributed under the terms and conditions of the Creative Commons Attribution (CC BY) license (http://creativecommons.org/licenses/by/4.0/). 